\title{
光源の振動を利用する小型距離センサ
}

\author{
王 欣 雨*・劉 \\ 忻*・篠 田 裕 之*
}

\section{A Small Range Finder Using Light Source Vibration ${ }^{\dagger}$}

\author{
Xinyu WANG*, Shin $\mathrm{LIU}^{*}$ and Hiroyuki ShINOdA ${ }^{*}$
}

\begin{abstract}
We propose a novel range finder composed of a point light source and a photodetector both of which are placed on a micro vibrator. The photodetector senses the reflected light intensity from the object surface and the amplitude of its fluctuation by the vibration. The distance is evaluated from the ratio of those two measured values. It is applicable to both a scattering surface and a mirror-like one, and it is stable against the dirt and the sensitivity fluctuation of the detector. Its expected applications range from medical treatment to new type of computer interface, such as a proximity sensor in minimally invasive surgery and a tongue motion sensor. The principle and experimental results using a prototype sensor are shown.
\end{abstract}

Key Words : position sensor, distance measurement, proximity sensor, living body surface, vibration

\section{1.はじめに}

世界の人々の行動範囲がグローバル化するにつれ，一部の 専門家だけでなく，一般の人が日常のコミュニケーション ツールとして外国語を話す能力が求められるようになってき た。しかし成人後に外国語の発音を会得することは必ずしも 簡単ではなく, 特に日本人が英語1), あるいは近年学習者が 増大している中国語の会話能力を習得する場合, 発音や発声 方法の違いによる困難が大きいと言われている.

たとえば中国語の基本音節は日本語の約 3 倍あり, 日本語 の範疇にはない音の違いを数多く聞き分け, 発音する必要が あるからである。この中国語発音の多様さの大部分は舌の位 置や形に深く関連する2),3) から，たとえば上下の歯のわずか な隙間を通して舌までの距離を測定できるセンサ5)があり, 自分で舌の位置を確認しながら発音学習が進められれば大変 能率が上がると考えられる. そのようなセンサは, 音声と舌 位置の関係を明らかにする基礎研究や, 計算機の新しいイン ターフェース, あるいは発音運動の混乱を抱える言語障害者 の治療の補助デバイスとしても応用可能と思われる.

一方マイクロカテーテルを用いた無侵襲外科手術は現代の 注目技術の一つである.しかし内視鏡を見ながらの操作は， 通常の手術における視覚と手指の関係とは異なっており, 特

\footnotetext{
†第 38 回 SICE 学術講演で発表 $(1999 \cdot 7)$

* 東京農工大学篠田研究室 小金井市中町 2-24-16 (現在 : 科学 技術振興事業団)

* Sinoda Lab. Tokyo University of Agriculture \& Technology 2-24-16 Naka-cho Koganei-city

(Received December 4, 2000)

(Received July 17, 2001)
}

に距離感がつかみにくいために誤操作が起こりやすい. 他臓 器への不用意な損傷を負わせる等の医療ミスがしばしば報告 され4), ここでも内視鏡から臟器までの距離を計測する小型 のセンサが望まれている.

このように生体表面に適用可能な小型の距離センサは多く の分野で潜在的に必要とされているが, よいセンサが存在し ないのが現状である，そこで本研究ではそのような要求を満 たすセンサを提案する。すでに我々は同様な目的で文献 5) に示すようなセンサを提案している，直進性の良いレーザー 光と球面波として伝播する LED 光を光ファイバで導入し, それらの散乱光を観測することでファイバ先端から対象面ま での距離を測定する。そのセンサは, 先端部が小型で, わず かな隙間から対象面までの距離を計測可能なものであった が, 濡れた表面のように鏡面反射性と散乱性を併せ持つ対象 表面についてはその原理上計測誤差が不可避であった.ここ では鏡面と散乱面のいずれにも適用でき，より安定な計測が 可能な新しい原理のセンサを提案する.

\section{2. 生体表面用小型距離センサ}

本研究では以下のような項目を満たす非接触距離センサを 開発することを目標とする。

(1) 小型 $(\mathrm{mm}$ オーダー程度)である.

(2) センサの精度は $1 \mathrm{~mm}$ 程度でよいが, 数センチメートル まで測定可能.

(3) センサ表面の污れなどに対して測定値が左右されにく く，大きな測定の詔りを起こしにくい.

(4) 被測定対象物の表面の傾きは未知でよい.

(5) 被測定対象物の表面の色や反射特性 (散乱性, 鏡面性) は 
未知でよい.

(6) 対象物の表面だけでなく，深部にまで到達した光の反射 が混入してもよい.

一般に非接触距離計測法としては，光を用いた 3 角測 量6), 波動の伝播時間や位相を測定するもの ${ }^{7}$, 対象像の焦 点距離検出 ${ }^{8)}$, 等を主な基本原理とする手法が数多く存在す る. しかし， 3 角測量法や焦点距離検出を基礎におく方法で は，センサのサイズを測定距離に対して小さくしていくと， 測定誤差が増大する (3 角測量法において二つの基準点から 目標点を見込む角度の測定誤差を一定とすると基準点間の距 離にほぼ反比例して測定誤差が増大する，付録参照)，光パ ルスの伝播時間を直接測定する方法でサブミリメートルの精 度を出すには, 解像度ピコ秒の受光素子を作る必要がある し，光の干渉を利用する方法はセンサ自身の污れや表面の性 状によって容易にコヒーレンスが損なわれてしまうことから 頑強な計測が難しい. 空中超音波の利用も一つの候補になり うるが，対象面が傾いたとき反射信号が消えてしまうため, 精度はおろか物体が存在することさえ見落としてしまう危険 がある。また $1 \mathrm{~mm}$ 径程度のビームを作るためには周波数を $1 \mathrm{MHz}$ 以上程度に設定する必要があり，その場合減衰距離 が $1 \mathrm{~cm}$ 程度になってしまう。このように従来の手法を用い て前述した(1)から (6)の制約条件を満たすセンサを実現するこ とは容易ではない. そこで本研究では光源, 受光素子の両方 を振動させることによって安定に距離を検出するセンサを提 案する. なお, 使用する光を可視光とすれば光が表面から侵 入する距離は多くの生体組織で $1 \mathrm{~mm}$ よりは十分小さいと考 えられるため, 項目(6)については考慮しなくてよいものとし て以下議論を進める。

\section{3. 基本 原理}

Fig. 1 に示すように点光源と受光素子が, $x$ 方向に振動可 能な振動体表面に装着された構造を考える. 発光, 受光素子 には図に示すような円筒が装着され, 空間的な選択性が付与 されている。いま振動体を一定振幅 $A$ で振動させ，そのと き受光される時間平均強度 $D$ と振動による強度変動の振幅 $\Delta D$ を観測量とする。このとき

$\Delta D / D$

によって対象物までの距離が計測されることを散乱体表面, および鏡面の二つの場合に分けて説明する.

\section{1 散乱性表面の場合}

光源をインコヒーレントな点光源とし, 観測面までの距離 を $x$, 観測点手前の空間の点 $\mathbf{r}$ (光源の位置を原点 $\mathbf{r}=0$ とす る) に到達する散乱光の強度を $I_{x}(\mathbf{r})$ とする. 光源が点とみ なせ，そこから球面波が伝播するのであれば，光源から直接 届く光の強度分布 $L(\mathbf{r})$ は相似則

$$
L(\mathbf{r} / a)=a^{2} L(\mathbf{r})
$$

を満たす。ここで $a$ は任意の正数であり, 各座標值での光 強度 $L$ を変化させずに空間軸を $a$ 倍することと, 空間軸は 変化させずに強度 $L(\mathbf{r})$ を $a^{2}$ 倍することが等価であることを
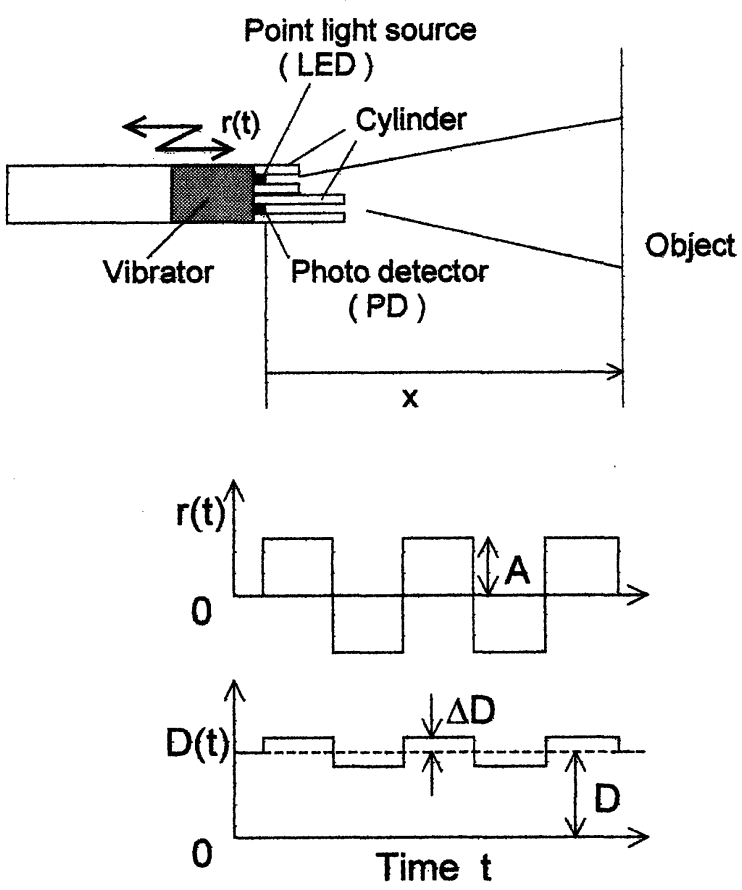

Fig. 1 Structure of the sensor and the sensing principle. The two cylinders attached to the LED and the PD localize the observation area. We estimate the distance $x$ from the $\Delta D$ and $D$ of the PD output for a constant displacement $A$ of the vibration.

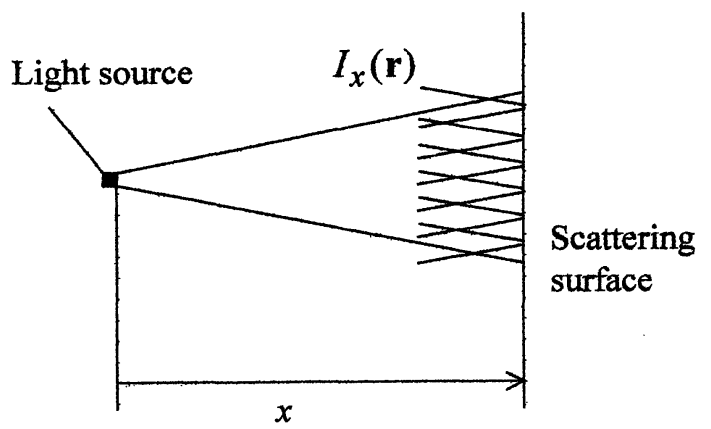

Fig. 2 Spatial intensity pattern $I_{x}(\mathbf{r})$ of reflected light from a scattering surface located at $x$

意味する．もし光が照射されている対象表面の散乱特性が空 間的に一様であれば $I_{x}(\mathbf{r})$ についても同様な相似則

$$
I_{x}(\mathbf{r})=I_{1}(\mathbf{r} / x) / x^{2}
$$

が成り立つと考えられる.ここで $I_{1}(\mathbf{r})$ は $x=1$ における散 乱光の強度分布である. この式は, 対象表面が $x=2$ に存在 する場合の光強度の空間分布が, 対象表面が $x=1$ に存在す る場合の分布の空間軸を 2 倍にし, 強度を $1 / 4$ にしたものに 等しい，ということを意味している．したがって $\mathbf{r}=0$ に設 置されたセンサに到達する光の強度 $D(x)=I_{x}(0)$ は $\beta$ を定 数として

$$
D(x)=\frac{\beta}{x^{2}}
$$

と書かれ，対象までの距離 $x$ の 2 乗に反比例する.一方振 動による強度変動の振幅は, 振動振幅 $A$ が小さい場合 


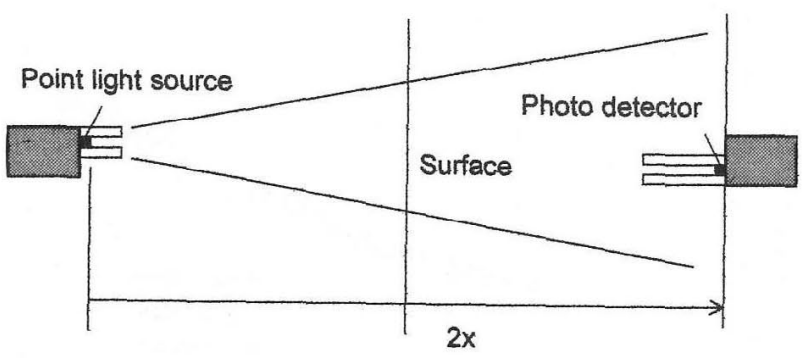

Fig. 3 Measuring a mirror-like object

$$
\Delta D(x) \approx A\left|\frac{d}{d x} D(x)\right|=\frac{2 A \beta}{x^{3}}
$$

のように $x$ の 3 乗に反比例するから，

$$
x=2 A D / \Delta D
$$

によって $x$ が求まる。Fig. 1 参照。振動振幅 $A$ が正確であ れば，発光および受光部の派れによる感度の変化や対象表面 の色は距離推定值に影響しない.

\section{2 鏡面の場合}

対象がセンサに正対した鏡面である場合にも先の議論はそ のまま成り立つが，より見通しをよくするため鏡像法を用い て考察してみる。すなわち受光部に到達する光波は自由空間 において受光部を Fig. 3のように鏡像点に配置した場合と 等価であるから， $\alpha$ を定数として

$$
D(x)=L(2 x, 0,0)=\frac{\alpha}{(2 x)^{2}}=\frac{\gamma}{x^{2}}
$$

となり，散乱性表面の場合と同じ計算

$$
x=2 A D / \Delta D
$$

によって $x$ が求まる。

このように本测定法では表面の反射の性質によらず正しい 距離を推定することができる。また，Dと $\Delta D$ は同一の素 子で観測され，その比が計測量となることから，素子感度の ばらつきやセンサ自身の污れなどにも強い計測法になってい る。

\section{4. センサの試作と基礎実験}

基礎実験として Fig.4 亿示すような装置を試作し，原理 を確認する実験を行なった。コイルを巻き付けた微小シリン ダーが動電駆動することによって, 光源と受光素子を振動さ せる。この実験での駆動系は目標サイズよりも大きいが，こ の改良ば今後の課題とする。受光素子に取り付けたシリン ダーは内径 $1 \mathrm{~mm}$ 外形 $1.2 \mathrm{~mm}$ であり, 以下に示す実験にお いては LED 側のシリンダーは取り付けずに行なった。フォ トダイオードの出力は近傍の FET で增幅する。

\section{1 基本特性の確認}

まず発光体の前面に受光素子を配置し，受光強度と距離の 関係を調べた。次にその中間地点に透過散乱体(紙)を設置 し, 同様に受光強度と距離の関係を調べた。その結果を Fig. 6 に重ねて表示する。いずれの場合にも，ほぼ距離の2 乗に逆比例して受光強度が減少していく様子が確認され, 直 接光の強度分布, 散乱光の強度分布のいずれについても原理

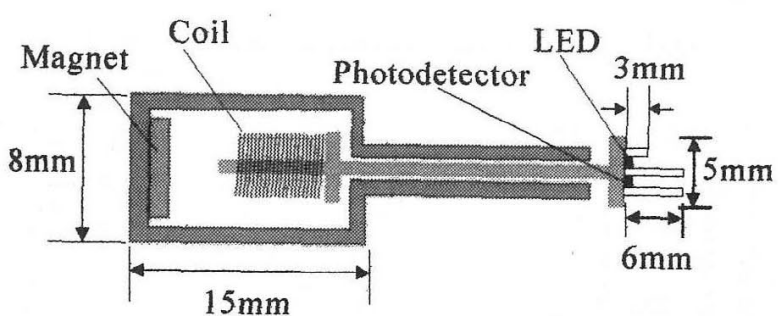

Fig. 4 A scale-up model of the micro range finder
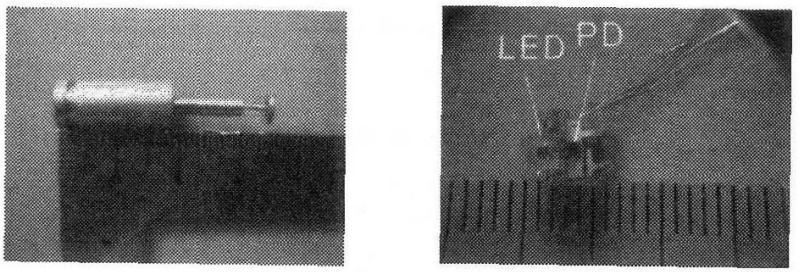

Fig. 5 Photograph of the prototype. A vibrator, left, and a sensor head without cylinders, right.

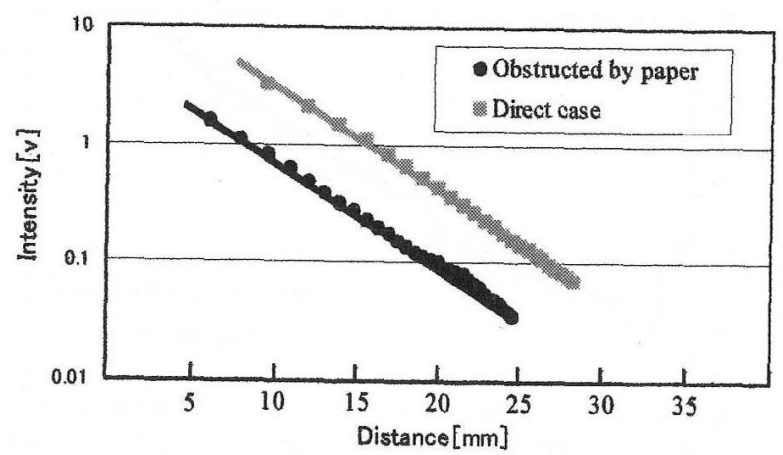

Fig. 6 Measured light intensity at various distances from the light source. Direct case indicates the data when there was no obstacle between the light source and the observation point. The data when a thin sheet of paper obstructed the direct light at the middle point are plotted with

で論じたような相似則と矛盾しない結果が得られた。

\section{2 受光素子の空間的選択性}

実験で用いたセンサにおいては，内径 $1 \mathrm{~mm}$ ，長さ $7 \mathrm{~mm}$ の金属円筒をフォトダイオードの先端に付けることによっ て, 受光素子の観測範囲を制限している。その観測領域を評 価した実験結果をFig. 7 に示す。

受光素子に微小テスト光源(直径 $1 \mathrm{~mm}$, 深さ $0.2 \mathrm{~mm}$ の 穴を通して LED を発光させる)を正対させ，受光素子を横 方向に $y \mathrm{~mm}$ 移動させたときに観測された受光強度を，そ の横方向移動量を横軸として Fig. 7 にプロットした。受光 素子と光源との距離が $1 ， 2 ， 3$ ，および $4 \mathrm{~cm}$ の場合につい て重ねて表示してある。図に見られるように，たと光ば観測 面の距離を $4 \mathrm{~cm}$ とすると，半径 $5 \mathrm{~mm}$ のスポットの外から の散乱光は受光素子に入射しないことがわかる.

\section{3 基礎理論を確かめる実験}

実際に光源を振動させ，センサ先端からの距離を変化させ ながら受光素子によって検出された光強度 $D$ および $\Delta D$ の 


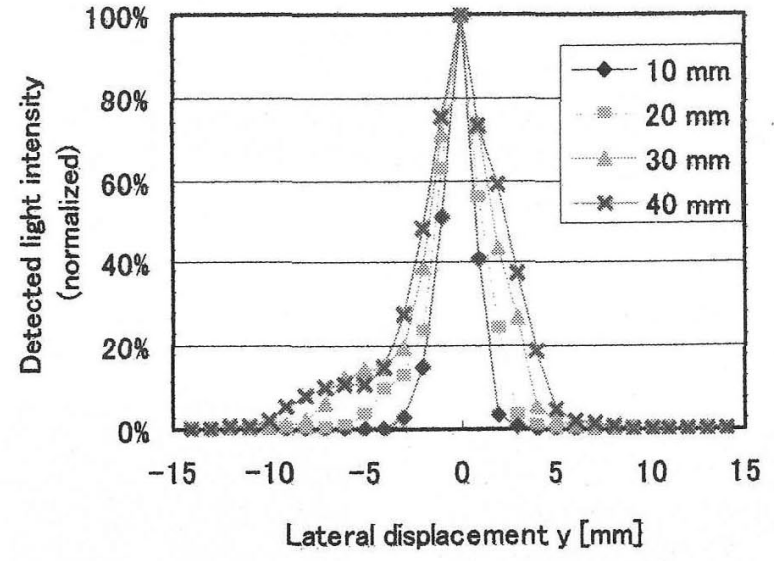

Fig. 7 Spatial selectivity of the photodetector. Detected light intensity for a point light source located on $x=10,20$, 30 , and $40 \mathrm{~mm}$ plane at $y[\mathrm{~mm}]$ from the center axis of the detector cylinder. The intensities are plotted being normalized so that the peak value equals to 1 .

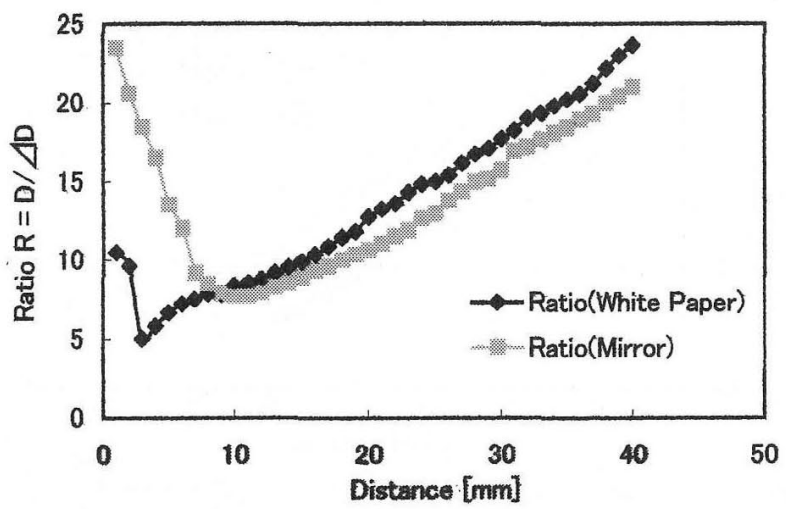

Fig. 8 Plots of the $R=D / \Delta D$ versus distance for a mirror surface and a white paper surface

\section{比をプロットした結果を Fig. 8 に示す.}

刘象面が紙のときと鏡面のときの結果をそれぞれの，四に 示す. $D(x)$ と $\Delta D(x)$ の比率 $R$ は理論的予想のと抢り, ほ ぼ $x$ の 1 乗に比例した。対象面が鏡の場合の曲線は，紙の 場合とは完全には一致していない。この理由は光源が受光素 子の隣に設置され，位置にずれがあるためと考えられるが， $10 \mathrm{~mm}$ 以上の場合はそのずれを推定誤差に換算すると $3 \mathrm{~mm}$ 程度である。な㧈 $D$ の検出においては光源を $200 \mathrm{~Hz}$ で変調 してその平均振幅を求めた。 $\Delta D$ については素子先端を振幅 $1 \mathrm{~mm}, 5 \mathrm{~Hz}$ で矩形的に振動させ (振幅は機械的に拘束), そ のとき受光される波形の包絡線(キャリアは $200 \mathrm{~Hz}$ )の $5 \mathrm{~Hz}$ 成分から求めた。

\section{5. 表面性状と傾きの影響}

基本原理を確認した上，様々な対象面を取り上げて，表面 性状の影響や表面の傾きの影響について調べた。

\section{1 表面色の影響}

生体表面の色は組織によって異なる91.ここでは，対象物 の表面色が測定に与える影響について調べた。対象物とし

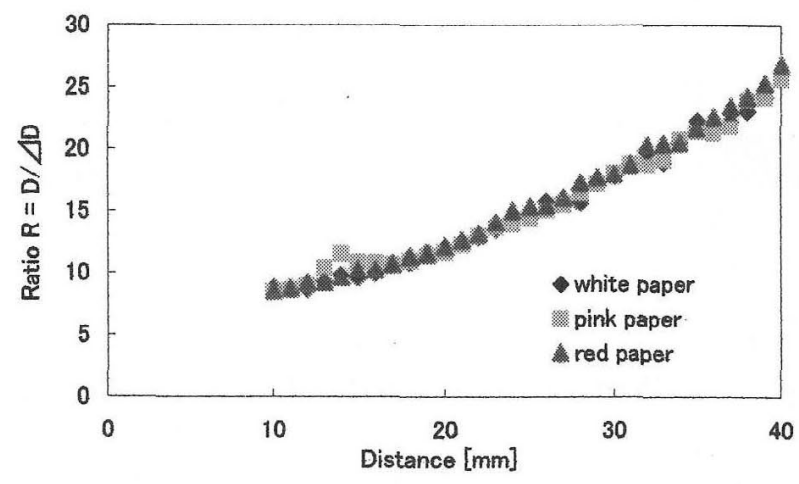

Fig. 9 Plots of the $R=D / \Delta D$ versus distance for different color surfaces

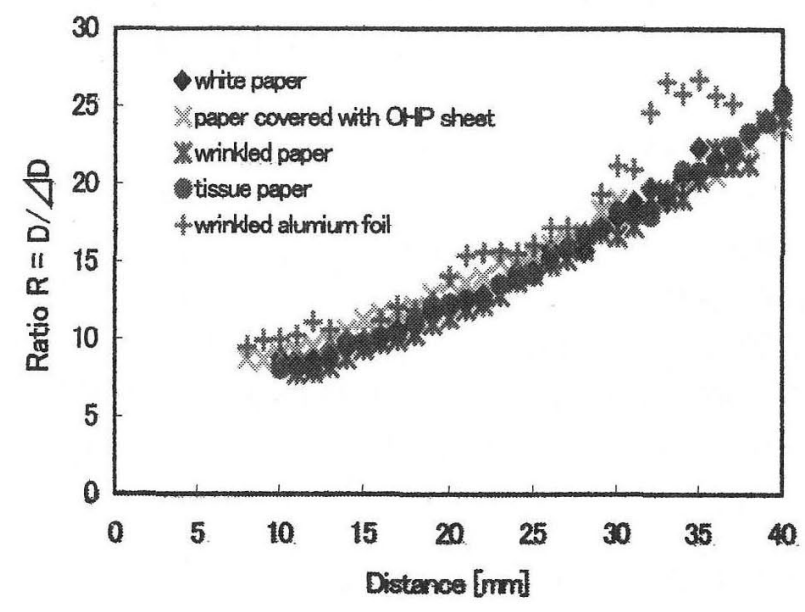

Fig. 10 Influence of surface configuration and reflection property. OIIP: a white paper surface covered with a transparent OHP sheet with thickness $0.1 \mathrm{~mm}$ simulating a wet surface. Wrinkled paper : randomly winkled paper. Wrinkled foil: randomly wrinkled aluminum foil. The width and height of each convexity of the roughness are $0.3 \sim 2 \mathrm{~mm}$ and $0.1 \sim 0.5 \mathrm{~mm}$, respectively

て, 白，赤，ピンクの三色の紙を用いて先ほどと同様な比 $R=D / \Delta D$ を測定した。その結果をFig.9 亿示す。図に示 すように，比 $R$ の曲線は対象物の色に関係なく，ほほ同比 率の曲線が得られた。

\section{2 表面性状の影響}

濡れている生体組織表面からの反射光に㧈いては，鏡面反 射と散乱の両成分が含まれていると考元られるが，このよう な状況を模擬するため, 紙に透明シート(厚さ $0.1 \mathrm{~mm}$ の OHP シート)を被覆し，その表面について同様な比 $R=D /$ $\Delta D$ を測定した。Fig. 10 亿示すように，紙の表面の場合と 大きな違いはみられなかった。次に対象物の表面が平滑でな い場合を評価するため，無作為にしわを作った紙と，アルミ 箔について実験を行なった。しわ付き紙は $0.1 \mathrm{~mm}^{2} \sim 5 \mathrm{~mm}^{2}$ 程度小さい散乱反射面の突起をもつ表面であり，アルミ䇴は 同程度の大きさの鏡面突起をもつ表面であった。Fig. 10 に 示すように，アルミ䈹については白い紙とは有意なずれが見 られた。これは測定原理の章で論じたような「対象面の反射 


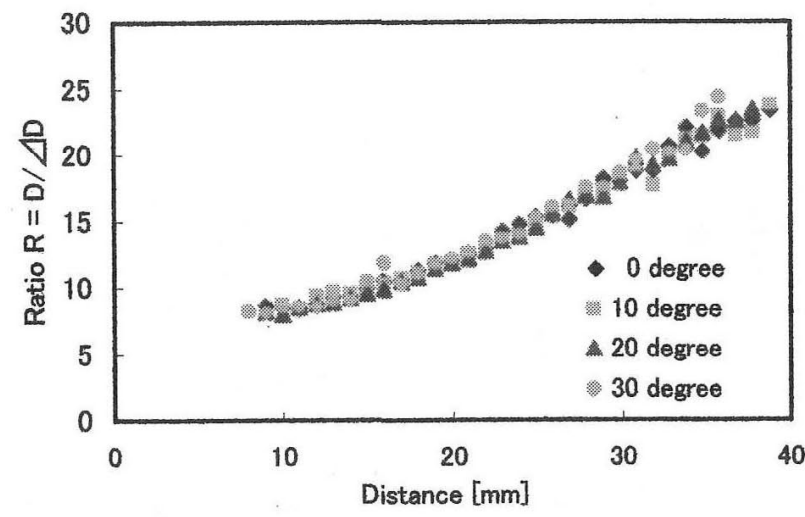

Fig. 11 Plots of the $R=D / \Delta D$ versus distance for inclined surfaces of white paper

の特性が空間的に一様である」という前提が成り立たないた めと考えられる。たとえば観測面を除々に遠ざけて行くこと を考えると, 突起上の反射面と観測点を結ぶ角度は一般に変 化していくから，その突起の面積が観測面の面積より十分小 さいと見なせない場合 (より厳密には振動による観測面の変 化量より十分小さいとみなせない場合)には誤差を引き起こ しうる。しかし同様な形状をもった表画においても，それが 散乱性の場合には平坦な場合と有意な差は見られなかった。

次に表面だけでなく深部にまで到達した光の散乱もが混入 してくる対象として，多孔性構造を持つティッシュペーパー を用いて，測定を行なった。 Fig. 10 に示すように，Rの計 測曲線は白紙の曲線とほぼ一致した。内部からの散乱光が混 入する場合には, その深さの平均的な值が扝扝むねの距離測 定值になると考えられる。人体組織の光吸収波長特性と考え ると, 波長 $650 \mathrm{~nm}$ から $700 \mathrm{~nm}$ の光が血液に浸透する深さ は $10^{-2} \mathrm{~mm} \sim 10^{-1} \mathrm{~mm}$ 未満と報告されている9)。人体組織全 般においてもこれと同程度と考えてよいとすれば，本実験で 用いている中心周波数 $660 \mathrm{~nm}$ の赤色 LED 光は, 組織表面 から $10^{-1} \mathrm{~mm}$ までの範囲で反射散乱されることになり,こ の問題は測定の障害にはならないと思われる。

\section{3 対象面の傾きの影響}

本センサがその出発点において想定した必須要件は，傾い た対象表面においても正しい測定值を与えることであった。 最初の章で論じたような応用のためには非常に重要な性質で ある。Fig. 11 は対象物を紙とし, それを傾けた場合に比 $R$ を測定した結果である。対象面を 10 度，20度，および 30 度傾けた場合の結果を重ねて表示したが, 比 $R$ は大きく変 わらず, 距離推定詔差に換算して $1 \mathrm{~mm}$ 程度以内のずれで あった。Fig. 12 は対象物として, 紙を透明 OHP フィルム で被覆したものを用いた場合の測定結果である。この場合， 対象物の傾きが大きくなるにつれて, 光強度比曲線も少しず つずれていく傾向がみられた。この主原因は鏡面反射成分が 受光素子に戻らなくなることから受光強度が減少し, SN 比 が低下したためと考えている。

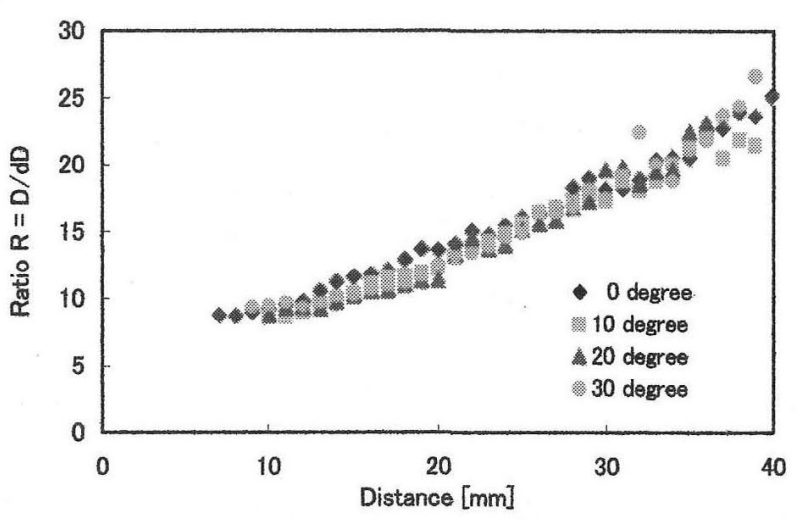

Fig. 12 Plots of the $R=D / \Delta D$ versus distance for inclined surfaces of white paper covered with a $0.1 \mathrm{~mm}$ transparent OHP sheet

\section{6. まとめと問題点}

本論文では小型の距離センサが広い分野で必要とされてい ることを指摘し, その応用に適した光距離センサを提案し た. 点光源とその受光素子を振動させ, 対象物からの散乱光 強度と, 振動によるその変動分を観測することで, センサ端 面から対象物表面までの距離を計測する。散乱性, 鏡面性, いずれの対象表面にも適用可能であり, 対象表面の角度, 反 射率は未知でもよい. センサ自身の污れに対しても頑強で, 対象の表面からだけでなくその内部からの反射が混入しても 大きな誤差を生じない。試作したセンサによって基礎原理を 検証し, 様々の対象物について測定の精度を評価した。その 結果, 特に数 $\mathrm{mm}$ 程度の凹凸鏡面をもつ対象以外では, 測 定箟囲 $30 \mathrm{~mm}$ までの測定精度は $\pm 2 \mathrm{~mm}$ 程度以内であった。 なお $10 \mathrm{~mm}$ より近い場合は測定不能であるが，これはセン サの基準位置を後方にずらせば良いので応用上問題となるこ とは少ないと考えられる。

今後はこれを舌位置センサに応用する研究や内視鏡下外科 手術における距離センサへと応用する研究に発展させていき たいと考えている。舌運動センサは, 発音と舌位置との明確 な関連を見出す研究, 中国語発音学習法の開発, 発音運動の 混乱を抱える言語障害者の診断・治療, あるいは新しいコン ピュータインターフェースとしての無声通信などへも応用可 能であると考えている。

最後には本手法の限界あるいは問題点を整理しておく。本 計測原理は式 ( 3 ) に書かれるような相似性を基礎にしている ため，これが成立しない対象には適用ができない。観測範囲 の中心から外側に向かって著しく変化する反射率分布が生じ てしまっている場合や，観測範囲と同定度の粗さをもつ凹凸 鏡面によって表面が構成されている場合には大きな誤差を生 じてしまうと考えられる。個別の応用に際し，これらがどの 程度影響するかを今後吟味していく予定である。また現段階 の試作センサにおいては駆動部分が大きく目標である $1 \mathrm{~mm}$ 程度のサイズにはまだ到達していない、ソレノイドによる駆 動は小型化が困難であるため, 現在空気圧による駆動方法を 
開発中である。

\section{付録〜三角測量の測定誤差}

二つの基準点を $\mathrm{A}$ および $\mathrm{B}$ とし，その間の距離を $a$ とす

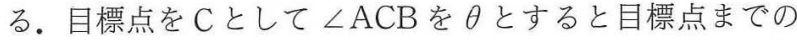
距離 $l$ と $a$ およ゙ $\theta$ は

$$
l \theta \approx a
$$

であるから， $\theta$ の測定誤差と距離 $l$ の推定誤差の関係は

$$
\delta l=\frac{a}{\theta^{2}} \delta \theta=\frac{l^{2}}{a} \delta \theta
$$

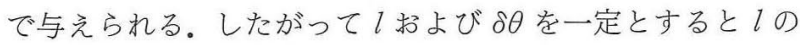
測定誤差は $a$ に反比例する。

\section{参 考 文 献}

1）竹林, 渡邊, 清水, 斎藤 : 初級英語音声学, 大修館出版社, 19/21, 31, 41, 51, 59/64, 78, 186/188 (1992)

2）張志公(編)：現代漢語, 人民教育出版社, I, 11/12, 16/21 (1982)

3） G. J. Borden \& K. S. Harris 著, 廣瀬肇訳：ことばの科学入 閅, メディカルリサーチセンター, 88/120(1994)

4）及川慶浩：腹腔鏡の手術とその看護, 小学館, $7 / 8,20 / 21,32 /$ 35 (1995)

5）王, 劉, 篠田：舌運動計測システムと中国語発音学習への心用, 電気学会論文誌 E, 119-4, 209/214(1999)

6）井口征士：広がりをみせる 3 次元計測技術, 計測と制御, 31-9, 968/947(1992)

7) M. Rioux : Laser Range Finder Based on Synchoronized Scanners, Applied Optics, 23-21, 3837/3844 (1984)

8）センサハンドブック：培風館, 427/429(1986)

9）久保宇市：医用レーザー入門, オーム社, 70/72(1985)

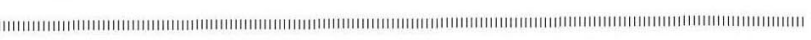

[著者紹 介]

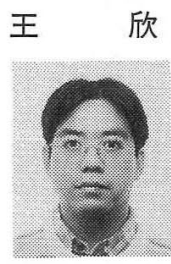

欣 雨 (学生会員)

1996 年東京農工大学工学部電子情報工学科卒 業. 同年同大学大学院電子情報工学専攻博士課程 入学. 投稿当時同専攻博士後期課程。現在科学技 術振興事業団光学用新材料チーム研究員, 工学博 士。言語に関連する新しい計測・学習システムや 光学用新材料による光センサの開発に興味をも つ. 日本中国語学会会員。

劉

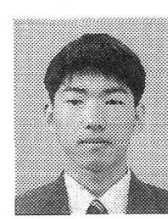

篠 田裕

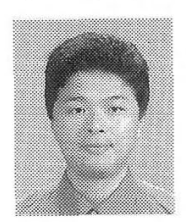

忻（正会員）

1998 年東京農工大学工学部電子情報工学科卒 業. 2000 年同大学大学院電子情報工学専攻修士 課程修了, 工学修士。光による生体計測システム に興味をもつ。現在オリンパス光学工業(株)勤 務。

之（正会員）

1988 年東京大学工学部物理工学科卒業. 90 年 同大学院計数工学修士, 90 年上り同大学助手, 95 年博士 (工学)。同年より東京農工大学講師, 97 年より同助教授, 99 年 UC Berkeley 客員研究 員, 2001 年より東京大学情報理工学系研究科助 教授。触覚を中心としたセンサシステムとデバイ ス, 触覚ディスプレイ, 光・音響計測などの研究 と教育に従事. 94 年佐藤記念知能ロボット研究 奚励賞, 93 年, 94 年, 98 年訫測白動制御学会論 文賞, 98 年日本機械学会部門賞, 99 年 IEEE ICRA The Best Conference Paper Award 受賞. 電気学会, 日本機械学会, 日本 VR 学会の会員. 